\title{
Enfermedad invasiva gastrointestinal por citomegalovirus resistente a ganciclovir
}

\author{
Juan Luís Ferreras Duarte
}

Servicio de Nefrología. Hospital Universitario Carlos Haya. Málaga.

\section{Introducción}

El citomegalovirus (CMV) es un virus ADN de doble cadena de la familia de los herpesvirus como el virus herpes simple o el de Epstein-Barr. La prevalencia del CMV en la población en general se acerca al $60 \%$, ello se debe a su fácil transmisión por vía oral, sexual, transfusiones y por transmisión perinatal. Por esto, la infección por CMV es una de las infecciones oportunistas más frecuentes en los trasplantados, responsable de las infecciones primarias y las reactivaciones del virus latente en inmunodeprimidos. La infección suele ser asintomática, pudiendo dar lugar a diferentes cuadros clínicos. Dependiendo del estado inmunitario del paciente la infección puede ser aguda, crónica, latente o reinfección.

En el paciente trasplantado renal suele cursar con un síndrome febril sin localización. El diagnóstico se realiza en el laboratorio de microbiología con técnicas de serología, aislamiento viral, detección del antígeno del virus o técnicas de biología molecular. Para ello se investiga la serología IgG de CMV mediante PCR (Polymerase Chain Reactión) en el donante y en el receptor $y$, posteriormente, se realizan controles periódicos en el receptor. Sólo si es CMV negativo se iniciará tratamiento profiláctico.

La profilaxis consiste en la administración de unos fármacos antivirales con actividad contra el CMV, como son el ganciclovir (Cymevene ${ }^{\circledR}$ ) o el foscarnet (Foscavir ${ }^{\circledR}$ ). El más usado es el ganciclovir; se usa en dosis endovenosas de $5 \mathrm{mg} / \mathrm{kg} / 12$ horas diluidos en

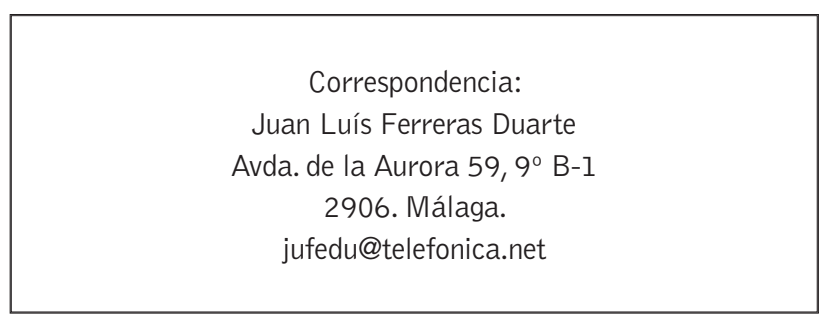

$100 \mathrm{ml}$ de salino o glucosado 5\% durante 14 días. Tras estas 14 dosis se vuelve a cuantificar la PCR y si es mayor de 400 se continua una semana más y se repite; si es menor de 400 se continua con la vía oral 2 gr/día durante 4 meses.

Actualmente utilizamos un nuevo fármaco, valganciclovir (Valcyte ${ }^{\circledR}$ ), que es un pro- fármaco del ganciclovir, es decir, que se metaboliza a ganciclovir, con una biodisponibilidad del 60\% (10 veces mayor que la que se consigue con las cápsulas de ganciclovir), con el que se consiguen niveles en sangre similares a los de ganciclovir IV, pudiendo excluir ésta vía y sus inconvenientes. La inducción comienza con dos comprimidos de $450 \mathrm{mg}$ de valganciclovir dos veces al día durante 21 días y el mantenimiento continua con dos comprimidos al día durante 7 días.

También mediremos la PCR cuando el donante y el receptor sean positivos o donante negativo y receptor positivo, en los que, si es mayor de 400 se utilizan las mismas pautas que con los donantes positivos y si es menor de 400 no se hace profilaxis. Aún así, la mejor profilaxis sería la selección de los donantes CMV negativos, pero eso es prácticamente imposible por razones obvias. A continuación presentamos un caso en el que el paciente presentó una afección por CMV.

\section{Antecedentes}

Paciente de 25 años con síndrome nefrótico corticorresistente desde 1984 con biopsia compatible con lesiones mínimas con inmunofluorescencia positiva a IgM. Desarrollo de insuficiencia renal en 1988; una segunda biopsia muestra esclerosis global focal con afectación intersticial secundaria. Se practica fístula arteriovenosa, aunque la insuficiencia renal permanece controlada hasta octubre de 2006, fecha en la que inicia hemodiálisis, tolerando bien las sesiones. En junio de 2007 recibe un trasplante renal de un donante cadáver, varón, de17 años, grupo 0, fallecido tras un traumatismo craneoencefálico. Son compa- 
tibles en DR y en B. Se pauta inmunosupresión con FK, mofetil micofenolato, prednisona. En el postoperatorio se constata un aumento de la diuresis sin mejoría de la función renal requiriendo de una sesión de hemodiálisis al octavo día postraslante; se realiza una biopsia del injerto el noveno día postrasplante y se inicia tratamiento empírico con dosis altas de esteroides. Biopsia con signos de rechazo agudo celular grado I-A de Banff. La respuesta al tratamiento es buena, con mejoría de la función renal, al alta, trece días después del ingreso, la creatinina es de $5,6 \mathrm{mg} /$ dl. Siendo la serología CMV donante positivo, receptora negativo, se inicia profilaxis con ganciclovir.

\section{Evolución postrasplante}

En la primera consulta ambulatoria, 16 días después del trasplante, la paciente presenta sensación de plenitud gástrica y distensión abdominal continua que obliga a disminuir la dosis de mofetil micofenolato, una semana más tarde continua con molestias, y a los pocos día presenta cuadro diarreico por lo que se vuelve a reducir la dosis de dicho fármaco quedando a la mitad.

La evolución en los siguientes cinco meses fue magnifica. La profilaxis anti-CMV se mantuvo con una dosis oral de 900 mgr diarios de valganciclovir durante casi 6 meses. Al suspenderse la medicación requiere un ingreso por diarreas y enfermedad por CMV, desde el 16 al 26 de diciembre, que obliga a iniciar de nuevo la profilaxis con valganciclovir (la PCR de CMV se ha mantenido negativa). A pesar del tratamiento ha persistido una febrícula diaria y molestias abdominales inespecíficas, sin náuseas ni vómitos, con malestar general y debilidad, por lo que se ingresa desde el 5 al 23 de enero para iniciar tratamiento intravenoso con ganciclovir. Desde el alta, aunque el estado general es bueno, se mantiene la febrícula diaria con picos febriles de hasta $38^{\circ} \mathrm{C}$ y epigastralgia intermitente que aumenta con la comida. Aparece una leucopenia que se trata con factores estimulantes de colonias, esto obliga a suspender el mofetil micofenolato para poder mantener la dosis de ganciclovir. La carga viral CMV fue descendiendo, siendo en el momento del alta negativa y el contaje de leucocitos normal.

Nuevo ingreso desde el 1 al 4 de febrero, durante el mismo mejoró el estado febril y el contaje de leucocitos. Se realizó biopsia por gastroscopia siendo la
PCR para CMV en tejido gástrico positiva. Desde entonces la cifra de leucocitos se recupera parcialmente, manteniéndose la febrícula de bajo grado. Cuando comienzan de nuevo los picos febriles diarios de hasta $38^{\circ}$ C. vuelve a ingresar (desde el 14 de febrero al 31 de marzo), presentando ulceras bucales en mucosa interna de labio inferior y en mucosa bucal de mejilla izquierda a pesar del tratamiento con nistatina, siendo la clínica digestiva prácticamente nula. Se solicitó TAC cervico-toraco y abdomino-pelvico, RX de tórax, analítica completa y nueva PCR-CMV en sangre, serología a brucela y a Epstein Barr. Ante los resultados negativos del TAC se plantea estudio de médula ósea como parte del protocolo para el estudio de "fiebre de origen desconocido".

La paciente se muestra asténica y hastiada; se le comenta la necesidad muy probable de transfusión, que no desea. Dada la persistencia de la febrícula y a la espera de los resultados del estudio de resistencias, se inicia tratamiento con Cytotec $®$.

Se localizó una mutación UL97, del CMV, específica de resistencia a ganciclovir, en la muestra de tejido gástrico, por lo que se decide sustituir el gancicovir por a foscarnet. Se continuó los días posteriores con tratamiento con este fármaco y ciprofloxacino, quedando la paciente afebril y asintomática tras dos semanas de tratamiento. No obstante, el acceso vascular planteaba problemas; el miembro superior derecho era el portador de la fístula y el izquierdo planteaba dificultades para canalizar la vía venosa. Como se preveía la necesidad de tratamiento endovenoso al menos 3 ó 4 semanas más y extracciones para analíticas casi a diario, se decide implantar un catéter con reservorio subcutáneo. Ante su mal estado anímico se le facilitan salidas ambulatorias desde el 9 de marzo y se le de alta el 31 de marzo. Durante los diez días siguientes se mantuvo afebril por lo que siguió control en la consulta de trasplantes y acudió a ponerse el tratamiento de forma ambulatoria hasta finalizar pauta intravenosa y pasar a valganciclovir oral.

\section{VALORACIÓN DE ENFERMERÍA}

El personal de enfermería conoce a la paciente desde muy joven, cuando inició el tratamiento hemodialítico en nuestras unidades y el seguimiento de sus múltiples ingresos en nuestro servicio se ha vivido como algo propio. 
Durante su ingreso en la unidad de trasplante renal en junio de 2007 manifestó los siguientes diagnósticos enfermeros:

- Riesgo de infección R/C:

- La inmunosupresión derivada del tratamiento farmacológico.

- Las técnicas terapéuticas invasivas y efectos derivados de la cirugía.

- Déficit de conocimientos sobre los efectos secundarios de la inmunosupresión.

- Riesgo de estreñimiento R/C cambio de hábitos higiénico-dietéticos y encamamiento/reposo, propios de la hospitalización.

- Riesgo de manejo ineficaz del régimen terapéutico personal $\mathrm{R} / \mathrm{C}$ un déficit de conocimientos sobre los autocuidados, la dieta y el tratamiento farmacológico.

- Alteración del patrón del sueño R/C ansiedad, estrés, ambiente desconocido o cambios en su hábito normal.

- Déficit de conocimientos: signos y síntomas de rechazo inmunológico del injerto renal.

- Dolor R/C la postura corporal debida a encajamiento, la limitación de movimientos y al proceso quirúrgico.

- Ansiedad/Temor R/C:

- El desconocimiento de los procesos relacionados con la intervención quirúrgica y las probabilidades de éxito del trasplante.

- La privación de contacto con sus allegados por aislamiento invertido, reclamo frecuentemente la presencia de su madre.

- Pérdida de control sobre la situación en que se encuentra.

Tras aproximadamente cinco meses desde el trasplante en la que mantuvo una situación estable salvo las molestias gástricas que tuvo desde el alta, comienza una serie de ingresos motivados fundamentalmente por la aparición de fiebre. En estos ingresos los diagnósticos enfermeros más prevalentes fueron:

Temor R/C el pronóstico reservado y respecto a la conservación del órgano, la continua presencia de fiebre y diarreas que le mantiene asténica y triste manifestada en reiteradas ocasiones por la paciente, presentando cuadros de opresión en el pecho y falta de aire.

- NIC: Asesoramiento, presencia y potenciación de la seguridad.
- NOC: Utiliza técnicas de conservación de la energía.

Ansiedad R/C la incertidumbre de su estado, por las múltiples pruebas a las que se debe someter, los controles analíticos, las numerosas canalizaciones de vías, las trasfusiones, etc. manifestado por la negativa, a veces, a someterse a dichas pruebas para aceptar posteriormente tras crisis de llanto.

- NIC: apoyo, asesoramiento y educación sanitaria a la familia.

- NOC: control del miedo. Busca información para reducir el miedo.

En el último ingreso, desde el 14 de febrero al 29 de marzo, el más largo y duro para la paciente y sus cuidadores, presentó además:

Afrontamiento familiar comprometido R/C la duración del proceso y manifestado por la continua demanda de información por parte de los familiares.

- NIC: apoyo, asesoramiento y educación sanitaria a la familia.

- NOC: preparación del cuidador familiar domiciliario.

Manejo efectivo del régimen terapéutico $\mathrm{R} / \mathrm{C}$ los cambios en el tratamiento y manifestado por las preguntas el personal de enfermería.

- NIC: Conducta de cumplimiento

- NOC: Educación sanitaria.

Los problemas de colaboración más importantes fueron:

Riesgo de infección secundaria a Inmunosupresión desde el trasplante en junio de 2007:

- NIC: Administración de medicación y protección contra infecciones.

- NOC. Estado inmune y control del riesgo.

\section{Riesgo derivado de acceso venoso (catéter venoso} central)

- NIC: Control de infecciones.

- NOC: Flujo de volumen en el rango esperado

Durante estos ingresos el personal de enfermería se mantuvo muy pendiente de todo el proceso, extremando el cuidado de las vías de Laura para evitar nuevas punciones y colaboró activamente en la actualización 
sobre el manejo del reservorio subcutáneo que hubo que implantarle. Se contactó con el Hospital de Día para informarnos ya que ellos lo utilizan con mucha frecuencia. El temor que manifestaba la paciente ante la colocación, manejo y el cuidado del catéter se palió tras el proceso de reajuste de conocimientos.

Debido a las crisis de ansiedad, la astenia y el desánimo de la paciente y, cuando su cuadro lo permitió, se le concedieron permisos domiciliarios desde el 9 de marzo para que permaneciera en su domicilio durante unas horas al día. Cuando venia a su tratamiento, el personal mantenía una charla previa con ella antes de proceder a canalizar el dispositivo, conminándole a que respirara hondo y que colaborara en la técnica.

En abril de 2008 la paciente estaba de alta, continuaba siendo portadora del reservorio, aceptando incluso que se le mantuviera el "gripper" (aguja con la que se canaliza el dispositivo) para la siguiente dosis de medicación (antes le aterrorizaba la idea de llevarlo canalizado a casa) y estaba pendiente de acabar las dosis intravenosas y pasar a la vía oral.

\section{Conclusión}

La Enfermedad Invasiva Gastrointestinal CMV resistente a ganciclovir es una patología poco frecuente. La agresividad del cuadro hace esencial el papel de la enfermería sobretodo en el apoyo psicológico al paciente que la padece, por lo que la actualización de conocimientos de los enfermeros ha sido clave en todo el proceso.

Queda de manifiesto que, a pesar de que la enfermería nefrológica pudiera considerarse como experta en el cuidado de pacientes crónicos, nos encontramos ante situaciones que nos ponen a prueba. Este cuadro que se manifiesta por fiebre alta que aparece y desaparece, procesos de intensa diarrea diurna y nocturna que ceden y vuelven a aparecer, que alterna momentos de calma que dan optimismo al paciente y a sus cuidadores para que, de súbito, vuelva a aparecer con el consiguiente desánimo por parte de todos, ha supuesto una dura prueba para el equipo de enfermería.

Nuestro premio es ver aparecer a Laura sonriente, sin fiebre, con buen aspecto y muy guapa.

\section{Agradecimiento}

A Eugenia Sola por su colaboración.

\section{Bibliografía}

1. Llinares $P$, Míguez E, Sánchez E. Infecciones por virus en el Trasplante Renal. En: Aguado JM. Infecciones en Pacientes Trasplantados. $2^{\mathrm{a}}$ ed. Elsevier; 2004. p.367-387.

2. Berlango Jiménez J, Crespo Montero R. Complicaciones en el Trasplante Renal. En: Andreu Périz L, Force Sanmartín E. La enfermería y el trasplante de órganos. Panamericana; 2004: p.115-132.

3. Escuela Universitaria de Ciencias de la Salud, LibroGuía de Experto Universitario en Enfermería Nefrológica, $2^{\mathrm{a}}$ revisión. 2005. p.383-412.

4. Johnson M, Maas M, Moorhead S. Clasificación de Resultados de Enfermería. $2^{a}$ ed. Harcourt; 2003.

5. McCloskey J C, Bulechek. Clasificación de Intervenciones de Enfermería. $3^{\text {a }}$ ed. Harcourt; 2003.

6. NANDA. Diagnósticos Enfermeros. Definiciones y Clasificación 2003-2004. Elsevier; 2004. 